\title{
Bone Tissue Engineering: Production of TNTZ Alloy by Powder Metallurgy
}

\author{
Raíssa Monteiro Pereira $^{1, *}\left(\mathbb{D}\right.$, Cristiane Yumi Koga-Ito ${ }^{2 \mathbb{C}}$, Sabrina Moura Rovetta ${ }^{2}{ }^{\circledR}$, Maria Alcionéia \\ de Carvalho Oliveira ${ }^{2 \mathbb{D}}$, Aline da Graça Sampaio ${ }^{2}{ }^{\mathbb{D}}$, Gabriela de Morais Gouvêia Lima ${ }^{2 \mathbb{D}}$, Vinicius \\ André Rodrigues Henriques 1,3 , (D) \\ 1 Technological Institute of Aeronautics - ITA/DCTA, São José dos Campos-SP, 12228-904, Brazil \\ 2 Institute of Science and Technology, São Paulo State University (UNESP), São José dos Campos-SP, 12245-000, Brazil \\ 3 Institute of Aeronautics and Space - IAE/DCTA, São José dos Campos-SP, 12228-904, Brazil \\ * Correspondence: mraissa02@gmail.com;
}

Scopus Author ID 57219203151

Received: 23.04.20215; Revised: 28.04.2021; Accepted: 1.06.2021; Published: 9.06.2021

\begin{abstract}
The demand for metallic biomaterials has increased proportionally to the number of elderly population and people who have bone disorders related to diseases, accidents, or premature wear. Because of this, the studies related to the development of metal alloys for applications in biomaterials have increased and Ti-29Nb-13Ta-4.6Zr (TNTZ) alloy received a great highlight. TNTZ alloy was obtained by powder metallurgy technique in order to study the microstructural development and investigate the interactions with in vivo environment. To perform this work, elementary powders were mixed in alloy stoichiometry, uniaxial and isostatically cold compacted and sintered in high vacuum $\left(10^{-5}\right.$ Torr) at temperatures from $800{ }^{\circ} \mathrm{C}$ up to $1600{ }^{\circ} \mathrm{C}$. X-ray diffractometry showed a tendency for $\beta$ phase stabilization at higher temperatures. The density and microhardness tests showed increasing results as the temperature increased, showing values of $5.7 \mathrm{~g} / \mathrm{cm}^{3}$ and $352 \mathrm{HV}$. The mechanical tests presented modulus of elasticity around $40 \mathrm{GPa}$, maximum compressive strength of $1018 \mathrm{MPa}$ and flexural strength of $1297 \mathrm{MPa}$. The biological tests of Ti-29Nb-13Ta-4.6Zr samples sintered at $1600{ }^{\circ} \mathrm{C}$ demonstrated antimicrobial activity against Candida albicans and Pseudomonas aeruginosa, reducing 36 and $60 \%$ and high in vivo biocompatibility, which supports their use in implants.
\end{abstract}

Keywords: titanium alloys; TNTZ; powder metallurgy; biomaterials; biocompatibility; microstructural development.

(C) 2021 by the authors. This article is an open-access article distributed under the terms and conditions of the Creative Commons Attribution (CC BY) license (https://creativecommons.org/licenses/by/4.0/).

\section{Introduction}

Metals and their alloys are widely used as biomaterials. Among these metals, titanium and its alloys have the highest biocompatibility [1]. Beyond that, Ti also exhibits high corrosion resistance and specific strength, which is the density ratio to strength. Because of this, the demand for Ti alloys as biomaterials has increased, and many studies on the use of $\mathrm{Ti}$ alloys for biomedical applications have been developed [2-4].

The initial approach of Ti alloys as bone implants started with $\alpha+\beta$ alloy Ti-6Al-4V. However, $\mathrm{Al}$ and V's components were pointed as hazardous elements due to their high toxic ions release in the living tissue environment [5-7]. This drawback made the research focus on alloys composed only with high biocompatible elements such as niobium $(\mathrm{Nb})$, tantalum $(\mathrm{Ta})$ and zirconium (Zr) [6]. 
The Ti alloys elaborated with $\mathrm{Nb}$, Ta and $\mathrm{Zr}$ represent the $\beta$ class alloys characterized by their higher biocompatibility and a lower value of Young's modulus. The reason that $\beta$ alloys are preferred in bone implant application is that they prevent the occurrence of stress shielding effect [8]. This phenomenon is responsible for promoting bone resorption and poor bone remodeling due to the great difference between the rigidity of the bone (10 - 30 GPa) and the implant [9-11]. This mismatch leads to a looseness of the implant, causing its failure [12].

The Ti-29Nb-13Ta-4.6Zr alloy (TNTZ) has received particular attention from worldwide scientific research due to its exceptional properties that include high specific strength, high deformability and superior biocompatibility and is currently the most studied titanium alloy for implants [13-16].

The TNTZ alloy was developed in Japan to guarantee superior properties to the conventional Ti-6Al-4V, Co-Cr-Mo and 316L stainless steel alloys, which can be applied to both dental and orthopedic implants [17,18]. Among its properties, the ones that stand out the most are the low values of elastic modulus (40 - $60 \mathrm{GPa})$, good resistance to fatigue and excellent bonding characteristics when in contact with bone tissue [19,20]. These characteristics make the TNTZ alloy very attractive for replacing bone tissue, hip joints and bone plates by preventing the phenomenon of stress shielding [21].

Some studies using the conventional manufacturing method showed that TNTZ alloy presents attractive mechanical and biocompatible properties. Niinomi, M. (2003) [19] evidenced that TNTZ alloy presents Young's modulus much lower than that of Ti-6Al-4V (ELI). The same author studied in 2018 the in vivo osteoconductivity of surface-modified TNTZ alloy, showing that this alloy has high potential to be applied as an orthopedic implant because it presented high osteoconductivity and corrosion resistance [20].

The progression of researches regarding this alloy composition suggests the high importance of this material in the biomedical field and the opportunity to think about alternative processing routes. Since the TNTZ alloy presents in its composition high levels of refractory elements $(\mathrm{Nb}$ and $\mathrm{Ta}$ ), its elaboration is complex in terms of obtaining a homogeneous microstructure free of precipitates or inhomogeneities [22].

To overcome this issue, in this work, the powder metallurgy (P/M) technique was used aiming to assure a high control of the chemical in order to obtain complex geometrical design parts with elevated microstructural homogenization [6,23]. P/M techniques have intrinsic advantages over the conventional melting metallurgical route, particularly in terms of costs and biocompatible properties [24,25].

$\mathrm{P} / \mathrm{M}$ method permits the production of parts with near-net shapes, which avoids the use of complex machining operations, including material losses. In addition, the process occurs under a solid-state diffusion, where titanium does not reach the molten state, which means that the process uses lower work temperatures [26,27]. In terms of biocompatibility, P/M may offer the advantage of a porous surface that enables the interlocking of the implant with the surrounding bone tissue via bone ingrowth, enhancing the synergy between the prosthesis and bone [24].

In this paper, all elemental powders were used in the hydrogenated state. The use of titanium hydride powder produces titanium alloy parts with high relative density, low oxygen content, and mechanical properties that meet the Aerospace Material Specification (AMS) requirements $[28,29]$.

This work aims to present an unprecedented investigation of the P/M-TNTZ microstructural evolution, including the behavior of the hydrided powder during sintering, to 
determine the influence of the key process variables on the alloy microstructure. Beyond that, biological tests were performed aiming at an efficient and safe application of P/M TNZT in surgical implants.

\section{Materials and Methods}

\subsection{Raw materials.}

The blended elemental method of hydride powders followed by uniaxial and cold isostatic pressing with subsequent densification by sintering was used to prepare the TNZT samples.

Titanium and zirconium hydride powders were obtained from sponge fines. Hydriding was carried out at $500{ }^{\circ} \mathrm{C}$, in a vacuum furnace, for $3 \mathrm{~h}$, under positive pressure. After cooling to room temperature, the friable hydride was milled in a titanium container in vacuum condition $\left(10^{-3}\right.$ Torr). Tantalum and niobium hydride powders were obtained using the same route, however, using machining chips and hydriding temperatures significantly higher $\left(800{ }^{\circ} \mathrm{C}\right)$. The particle size measurements of the powders were carried out by Mastersizer 3000E equipment and are shown in Table 1.

Table 1. Particle size measurements

\begin{tabular}{c|c|c|c|c} 
Characteristic $^{*}$ & Ti & Nb & Ta & Zr \\
\hline D10 $(\boldsymbol{\mu m})$ & 1.10 & 1.26 & 0.84 & 0.90 \\
\hline D50 $(\boldsymbol{\mu m})$ & 2.84 & 6.98 & 4.22 & 4.56 \\
\hline D90 $(\boldsymbol{\mu m})$ & 15.20 & 21.50 & 20.40 & 20.00
\end{tabular}

* D10: The portion of particles with equivalent spherical diameters smaller than this value is 10\%; D50: The portions of particles with diameters smaller and larger than this value are 50\% (Also known as the median diameter); D90: The portion of particles with diameters below this value is $90 \%$.

\subsection{Preparation and sintering.}

Initially, the powders were weighted in the alloy's stoichiometry to obtain $100 \mathrm{~g}$ of mixture. Then, the powders were blended for $1 \mathrm{~h}$ in a Y-shaped mixer. After blending, powders were cold uniaxially pressed at $100 \mathrm{MPa}$, in a cylindrical $10 \mathrm{~mm}$ diameter steel die without lubricants. Afterward, the green compacts were encapsulated under vacuum in flexible latex molds and cold isostatically pressed at $450 \mathrm{MPa}$ during $30 \mathrm{~s}$, aiming to increase their green density.

Sintering was carried out in high vacuum condition $\left(10^{-5}\right.$ Torr $)$ inside a niobium crucible using Oxy-gon FC 530 model with tungsten heat zone furnace. The sintering temperatures were ranged from $800{ }^{\circ} \mathrm{C}$ up to $1600^{\circ} \mathrm{C}$, with heating rates of $20^{\circ} \mathrm{C} / \mathrm{min}$. After reaching the nominal temperatures, samples were held for $1 \mathrm{~h}$ and then furnace-cooled to room temperature.

\subsection{Microstructural characterization.}

For microstructural characterization of TNTZ sintered samples, the conventional steps of metallographic preparation were followed. To start, the samples were mounted in bakelite and then sanded with sheets of sandpaper with different grit sizes: 120 (coarse), 220, 400 and 600 (fine). Afterward, the samples were polished with a solution of alumina $(1 \mu \mathrm{m})$ and oxalic acid. In the next step, the samples were etched with Kroll solution (3 mL HF: 6 mL HNO 3 : 100 $\mathrm{mL} \mathrm{H}_{2} \mathrm{O}$ ) to reveal their microstructure. Micrographs were obtained using SEM Tescan model Vega 3, in the backscattered mode (BSE). Dispersive energy spectrometry (EDS) analysis was 
performed to identify the elements in dissolution. The density was measured by the Archimedes method and the phases present during sintering were analyzed by $\mathrm{x}$-ray diffractometry (XRD) using a Panalytical model X'Pert Pro equipment.

\subsection{Mechanical characterization.}

Samples of TNTZ alloy sintered at $1600{ }^{\circ} \mathrm{C}$ were characterized by microhardness, compression and bending test. The microhardness was determined by Emcotest DuraScan equipment applying a load of $0.2 \mathrm{kgf}$.

In order to obtain Young's modulus (E) of the TNTZ processed by P/M technique, it was performed a mechanical compression and a bending test. Mechanical compression tests were performed in a Universal Testing Machine MTS-810 at room temperature with a strain rate of $0.005 \mathrm{~mm} / \mathrm{mm} . \mathrm{min}$, using 6 cylindrical specimens (diameter: $5.2 \mathrm{~mm}$, height: $16 \mathrm{~mm}$ ) with strain gages by ASTM E9-19 standard [30]. Mechanical bending test was carried out in an MTS LANDMARK equipment with the 3 points bending configuration at room temperature and at a strain rate of $0.005 \mathrm{~mm} / \mathrm{mm}$.min using 16 sintered bars $(4.5 \mathrm{~mm}$ of width $\mathrm{x} 3.5 \mathrm{~mm}$ de height x $42 \mathrm{~mm}$ length) by ASTM E855-8 standard [31].

\subsection{Biological characterization.}

The study of the biologic properties from TNZT samples sintered at $1600^{\circ} \mathrm{C}$ was performed in two steps. In the first step, in vitro assays were developed to assess the microbial biofilm formation on TNTZ alloy and the cytotoxicity of Vero cells. In the second step, the material's biocompatibility was assessed by an in vivo assay using a murine model.

\subsubsection{Microbial biofilm formation.}

The biofilm assays used reference strains of three microbial species: Pseudomonas aeruginosa ATCC 15442, a Gram-negative bacillus; methicillin-resistant Staphylococcus aureus (MRSA) ATCC 33591, a Gram-positive coccus, and Candida albicans SC 5314, opportunistic fungal species. The bacterial strains were plated on Tryptic soy agar (TSA) and fungal strain on Sabouraud dextrose (SD) and incubated for $24 \mathrm{~h}$ at $37{ }^{\circ} \mathrm{C}$. After this period, standardized suspensions $\left(10^{6}\right.$ cells $/ \mathrm{ml}$ ) of $P$. aeruginosa (OD: $\left.0.115 \lambda: 600\right)$, S. aureus MRSA (OD: $0.462 \lambda$ : 600) and Candida albicans SC 5314(OD: 0.180 $\lambda$ : 530) were prepared in sterile saline solution $(\mathrm{NaCl} 0.9 \%)$, with the aid of a spectrophotometer.

Biofilm formation assays were performed on 24-well plates. Standardized samples of TNTZ sintered at $1600{ }^{\circ} \mathrm{C}(\mathrm{n}=12$ for each group) were sterilized by autoclave and added to wells, under sterile conditions, with the aid of a laminar flow chamber. The control group was composed by Ti-6Al-4V specimens obtained by P/M route $(n=12)$.

After, $2 \mathrm{~mL}$ of Tryptic soy broth or RPMI broth were added to the wells for assays with bacteria or C. albicans, respectively. An aliquot of $200 \mu \mathrm{L}$ of previously standardized microbial suspensions was transferred to each well. The plates were incubated at $37^{\circ} \mathrm{C}$, under agitation (75 rpm), for $90 \mathrm{~min}$ for the pre-adhesion phase. Then, the samples were washed with sterile saline solution $(500 \mu \mathrm{L})$, adding fresh culture medium and incubated for a total period of $48 \mathrm{~h}$. The culture medium was refreshed after $24 \mathrm{~h}$ of incubation.

Afterward, biofilms were washed with sterile saline and dispersed in $1 \mathrm{~mL}$ of a saline solution under sonication. The microbial suspensions were plated on TSA (for bacteria) or Sabouraud dextrose agar (for C. albicans) and incubated for $24 \mathrm{~h}$ at $37^{\circ} \mathrm{C}$, under aerobiosis. 
After this incubation period, the number of colonies was counted and the value of colonyforming units per specimen (CFU/specimen) was calculated. The tests were performed in triplicate in three independent experiments. Data of CFU/specimen were compared statistically between the groups by Normality test (post-hoc Shapiro-Wilk) and preceded by One-way ANOVA and Tukey's multiple comparison test. The level of significance adopted was $5 \%$.

\subsubsection{In vitro cytotoxicity on Vero cells.}

According to Kido methodology, the cytotoxicity of TNTZ alloy was assessed upon Vero cells (fibroblast-like from a kidney of green monkey) [32]. The cells were grown in 96well plates by using DMEM (Dulbecco's Modified Eagle's medium) supplemented with inactivated fetal bovine serum, $100 \mathrm{IU} / \mathrm{mL}$ penicillin and $100 \mu \mathrm{g} / \mathrm{mL}$ streptomycin. Plates were incubated at $37{ }^{\circ} \mathrm{C}$ and $5 \% \mathrm{CO}_{2}$. To obtain the culture medium containing the leachate from the testing material (TNTZ alloy, $n=9$ ), the specimens were previously prepared and sterilized by autoclave. For comparative purposes, specimens of Ti-6Al-4V alloy with the same dimensions were prepared and autoclaved $(n=9)$. The specimens were kept in DMEM medium for 7 days (1 specimen $+2 \mathrm{~mL}$ of DMEM). After this conditioning period, the DMEM was removed and the specimen was submerged in $2 \mathrm{~mL}$ of DMEM medium supplemented for 24

$\mathrm{h}$. This medium exposed for $24 \mathrm{~h}$ to the materials was diluted to obtain the concentration of 50 $\%$, placed in contact with the cells in culture. To assess cell viability, MTT method was used. Three independent experiments were carried out in triplicate. The results were expressed as a percentage of viable cells (\%), using the number of cells grown in a non-exposed culture medium as the negative control (100\% viability). Samples were assayed directly or after extraction with a cell-culture medium as described in guideline ISO 10993-10:2002 [33].

\subsubsection{In vivo biocompatibility test.}

In vivo biocompatibility test was performed by implanting TNTZ alloy specimens in subcutaneous tissue according to the ISO 10993 standard [34] following the protocol approved by the Research Ethics Committee with Experimental Animals No. 02/2019.

Briefly, five male Wistar rats (Rattus norvegicus), 60 days old, were used. The animals were maintained in cycle $12 \mathrm{~h}$ light and dark and received food and water ad libitum. The animals were anesthetized with intramuscular injections of a $10 \%$ ketamine solution (Dopalen - Ceva, Brazil; $0.2 \mathrm{~mL} / 100 \mathrm{~g}$ of body weight) and $2 \%$ xylazine (Anasedan - Ceva, Brazil; $0.1 \mathrm{~mL} / 100$ $\mathrm{g}$ of the animal). A standardized region on the dorsum of each animal was determined to perform the trichotomy. Then, the region was submitted to antisepsis with povidone iodine (10 $\%$ povidone aqueous solution with $1 \%$ free iodine). The sterile TNTZ alloy specimens (5 mm in diameter and $1 \mathrm{~mm}$ in thickness) were implanted between the subcutaneous tissue and the muscular fascia with subsequent sutures of the tissues with 4-0 nylon thread. The control group $(n=1)$ was submitted to the same anesthesia and sham surgery procedures with no specimen insertion. The animals were sacrificed 14 days after surgery and the implant-tissue compounds were harvested and immersed in $10 \%$ formalin fixative, washed, processed and paraffinembedded. After, semi-serial $5 \mu \mathrm{m}$ sections were obtained and stained with HE (HematoxylinEosin). Two random sections located in different depths were analyzed at 200x and 400x magnification. Tissue repair evidence and type of inflammatory alterations were analyzed. 


\section{Results and Discussion}

\subsection{Microstructural development.}

\subsubsection{SEM analysis.}

The study of the microstructural development TNTZ samples during sintering between $800^{\circ} \mathrm{C}$ to $1600^{\circ} \mathrm{C}$, indicated the development of the $\beta$ phase from the dissolution of the Ta and $\mathrm{Nb}$ particles. $\mathrm{Zr}$ is generally considered a neutral element and dissolves rapidly in the titanium matrix. However, recent studies indicate that $\mathrm{Zr}$ also acts as a $\beta$ stabilizer when in solid solution with other $\beta$ stabilizers such as Mo, $\mathrm{Nb}$ and Ta $[8,35,36]$.

At $800{ }^{\circ} \mathrm{C}$, the presence of particles from all alloy elements is observed, except for $\mathrm{Zr}$. It is also observed the beginning of $\alpha+\beta$ microstructure formation close to regions containing $\mathrm{Ti}$ particles. The darkest areas are regions containing $\mathrm{Ti}$. The gray areas contain $\mathrm{Nb}$ primarily and the lighter areas contain Ta. The presence of Widmanstätten-like microstructure $(\alpha+\beta)$ at this temperature is mainly related to the dissolution of regions containing $\mathrm{Zr}$ particles (Figure $1)$.
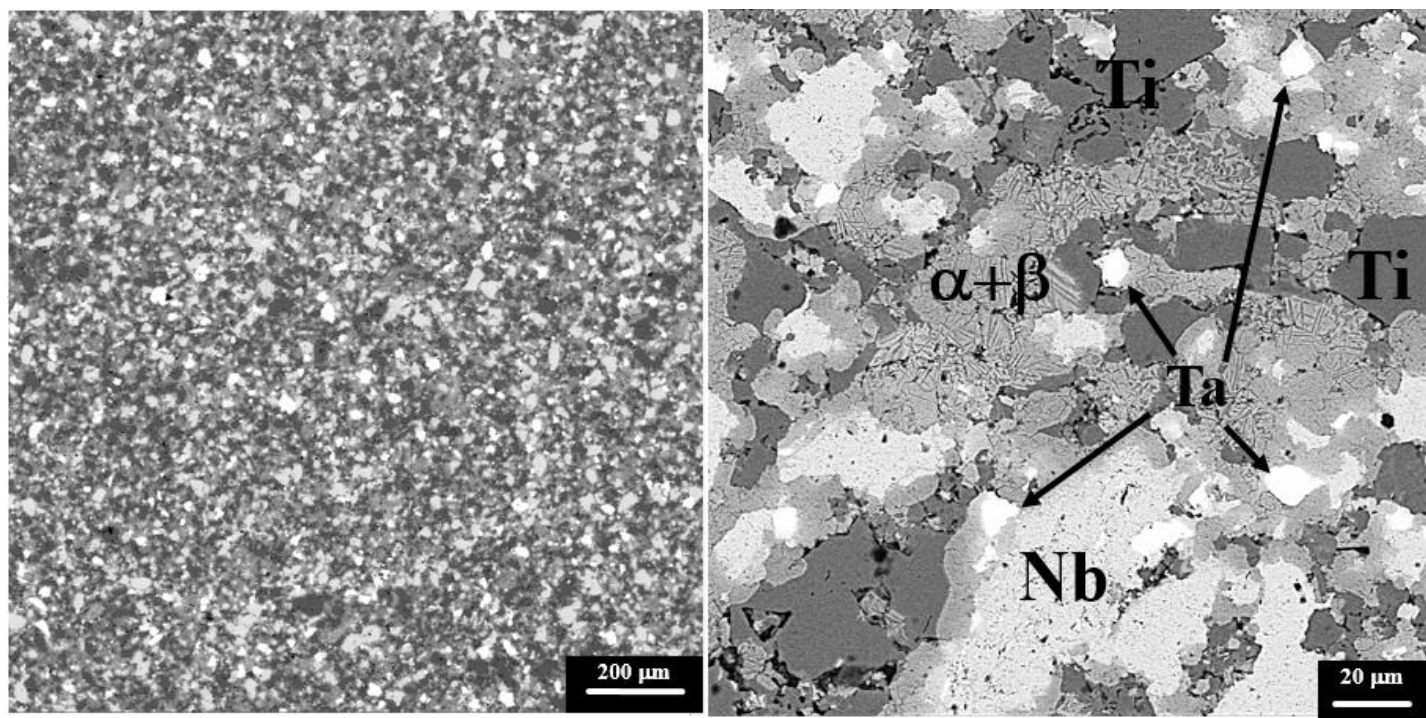

Figure 1. Microstructural development of the Ti-29Nb-13Ta-4,6Zr alloy sintered at temperatures of $800{ }^{\circ} \mathrm{C}$ obtained by SEM.

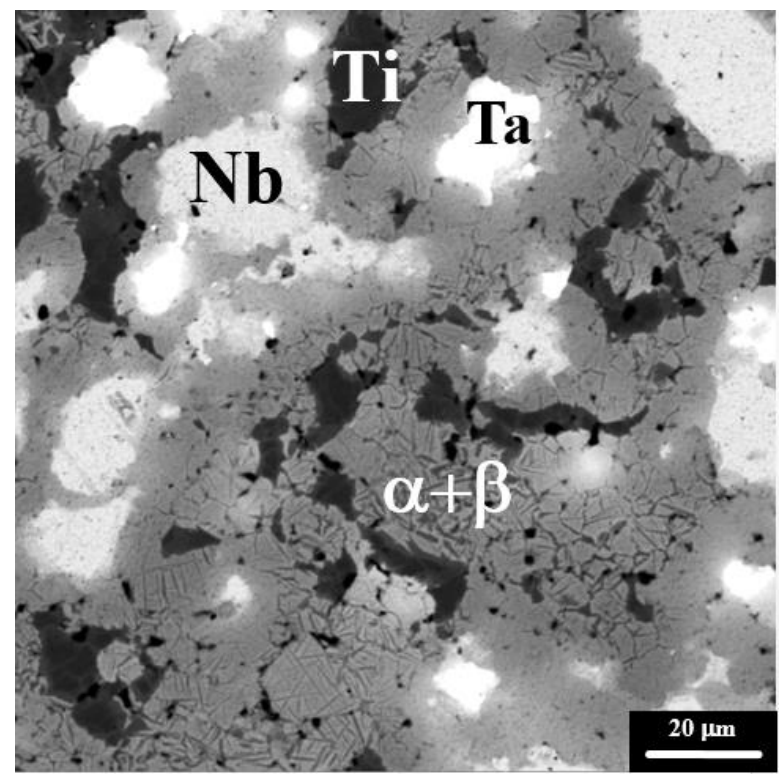

Figure 2. Microstructural development of the Ti-29Nb-13Ta-4,6Zr alloy sintered at $900{ }^{\circ} \mathrm{C}(\mathrm{SEM})$. 
At $900{ }^{\circ} \mathrm{C}, \mathrm{Nb}$ and $\mathrm{Ta}$ particles are still evident in the microstructure, showing their reduced dissolution in the titanium matrix. This indicates the need for an increment in the temperature in order to dissolve these elements. The $\alpha+\beta$ regions are composed of $\mathrm{Zr}$ in dissolution and/or areas with a high concentration of Ti that suffered diffusion of $\mathrm{Ta}$ and $\mathrm{Nb}$. In this stage, there is also the presence of a considerable number of pores with irregular geometry located in the interface between the particles and in their interior. This porosity tends to reduce as the temperature increases [37]. In Figure 2 it is possible to observe the microstructure present at $900{ }^{\circ} \mathrm{C}$.

At $1000{ }^{\circ} \mathrm{C}$, the former angular-shaped niobium particles become rounded. This indicates the loss of its angular geometry due to the diffusion processes that occur more strongly as the sintering temperature rises [37]. It is still possible to visualize the presence of large nuclei of $\mathrm{Nb}$ and $\mathrm{Ta}$, biphasic regions $\alpha+\beta$ and regions containing only Ti. In Figure 3 it the microstructure is shown present at $1000{ }^{\circ} \mathrm{C}$.

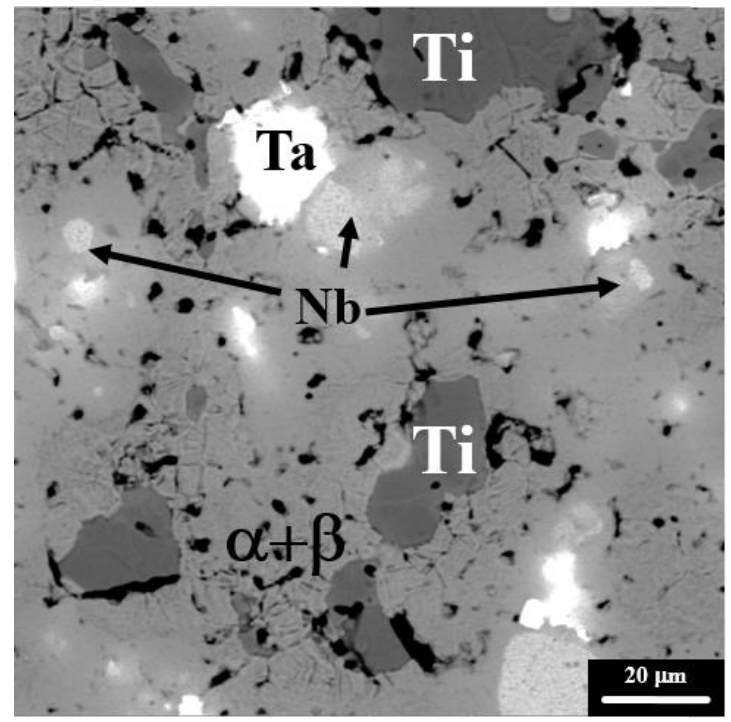

Figure 3. Microstructural development of the Ti-29Nb-13Ta-4,6Zr alloy sintered at $1000{ }^{\circ} \mathrm{C}(\mathrm{SEM})$.

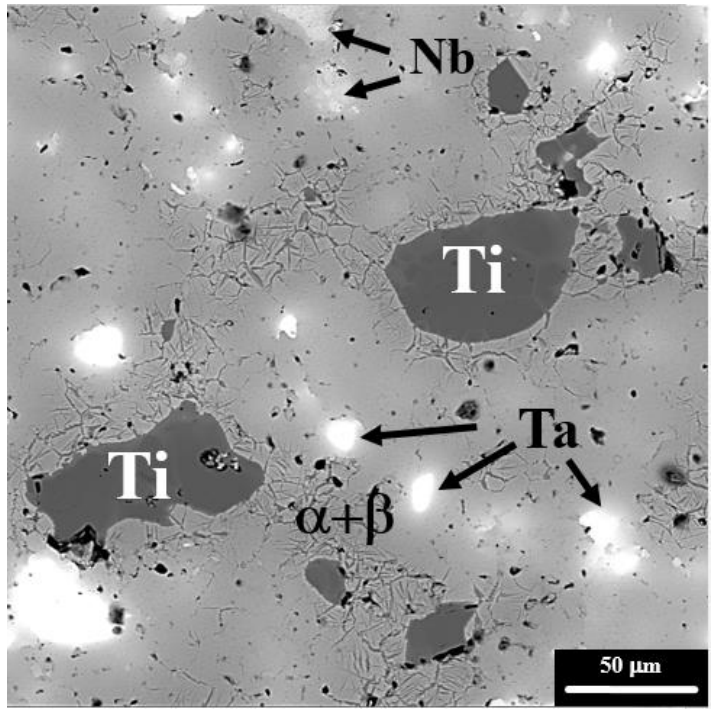

Figure 4. Microstructural development of the Ti-29Nb-13Ta-4,6Zr alloy sintered at $1100{ }^{\circ} \mathrm{C}(\mathrm{SEM})$.

At $1100{ }^{\circ} \mathrm{C}$, it is observed that $\mathrm{Nb}$ particles are dissolving faster than Ta particles, which is consistent with its lower melting point. The two-phase microstructure encloses the $\mathrm{Ti}$ particles that are still in dissolution. $\mathrm{Nb}$ and Ta particles ( $\beta$ stabilizers) are surrounded by the $\beta$ regions (Figure 4). 
Between $1200{ }^{\circ} \mathrm{C}$ to $1300{ }^{\circ} \mathrm{C}$, it is possible to notice that the $\mathrm{Nb}$ particles dissolve faster than the Ta particles, as seen in Figure 5. At these temperatures, areas containing only Ti were replaced by regions containing $\alpha+\beta$ microstructure and by single-phase $\beta$ regions.
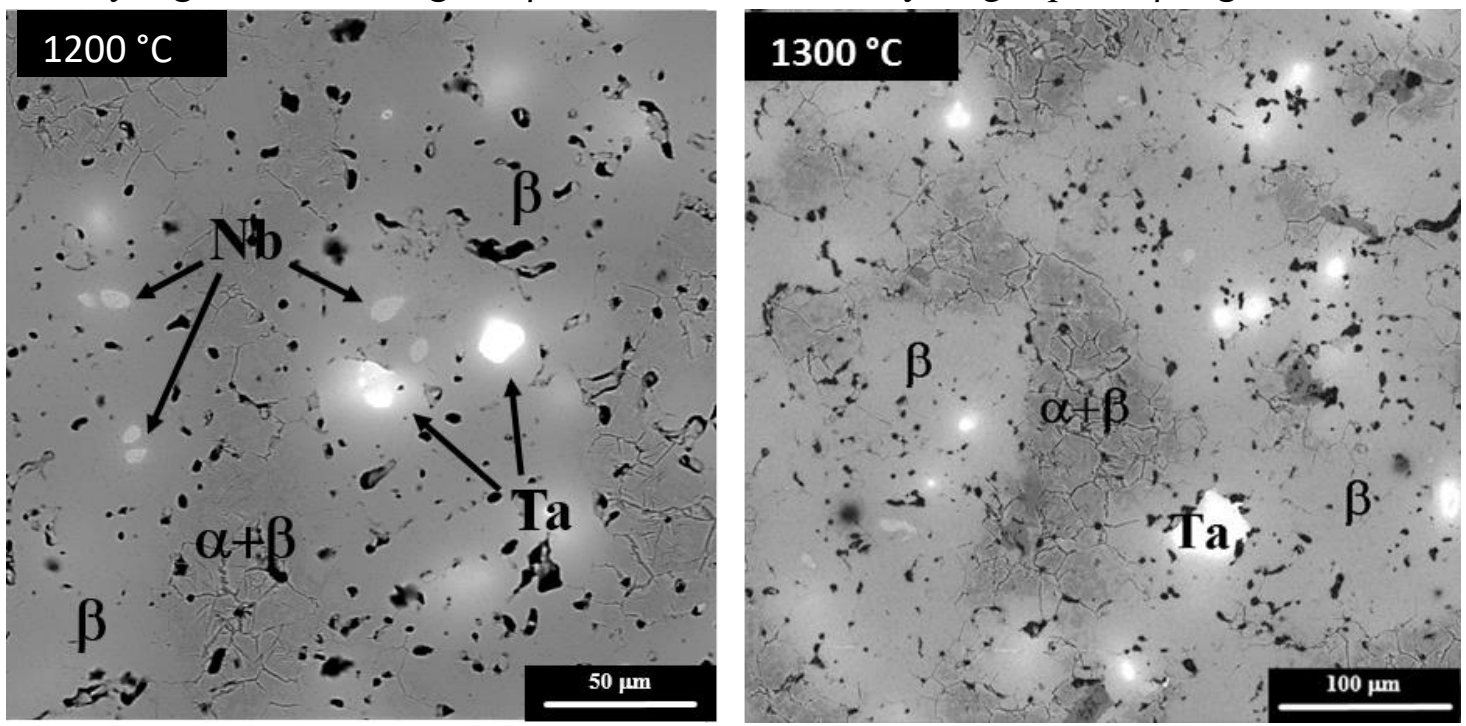

Figure 5. Microstructural development of the Ti-29Nb-13Ta-4,6Zr alloy sintered at $1200{ }^{\circ} \mathrm{C}$ and $1300{ }^{\circ} \mathrm{C}$ (SEM).

At $1400{ }^{\circ} \mathrm{C}$, areas with $\mathrm{Nb}$ nuclei are completely dissolved. Figure 6 shows that the predominance of $\beta$ and $\alpha+\beta$ areas is no longer noticed. However, it is still possible to notice the presence of Ta regions. Due to its high melting point, the Ta element is the last element to dissolve in the $\mathrm{Ti}$ matrix, becoming the microstructural homogenization dependent on its complete dissolution.

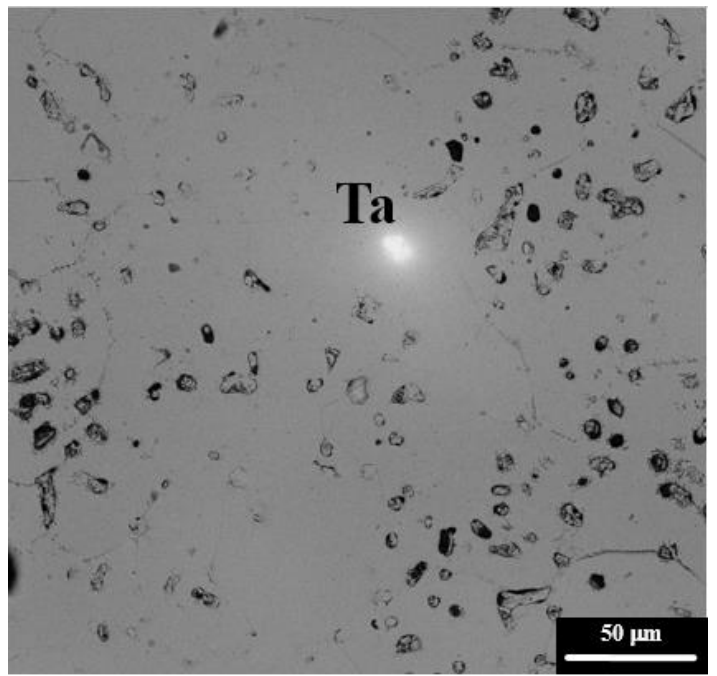

Figure 6. Microstructural development of the Ti-29Nb-13Ta-4,6Zr alloy sintered at $1400{ }^{\circ} \mathrm{C}$ obtained (SEM).

At $1500{ }^{\circ} \mathrm{C}$, the microstructure is almost completely homogeneous. However, lighter areas still enriched with tantalum are observed, as evidenced by EDS mapping, where the dissolution of the last regions rich in Ta was detected in this temperature. Thus, it was necessary to increase the sintering temperature for the total dissolution and homogenization of the elements.

The complete dissolution of all the elements is only verified at $1600{ }^{\circ} \mathrm{C}$, in which a homogeneous $\beta$-like microstructure is observed is throughout the sample. The presence of residual porosity in spherical geometry is also observed. This is associated with the final stage 
of sintering, where there is a migration from the smallest to the largest pores from the Ostwald ripening effect [28].
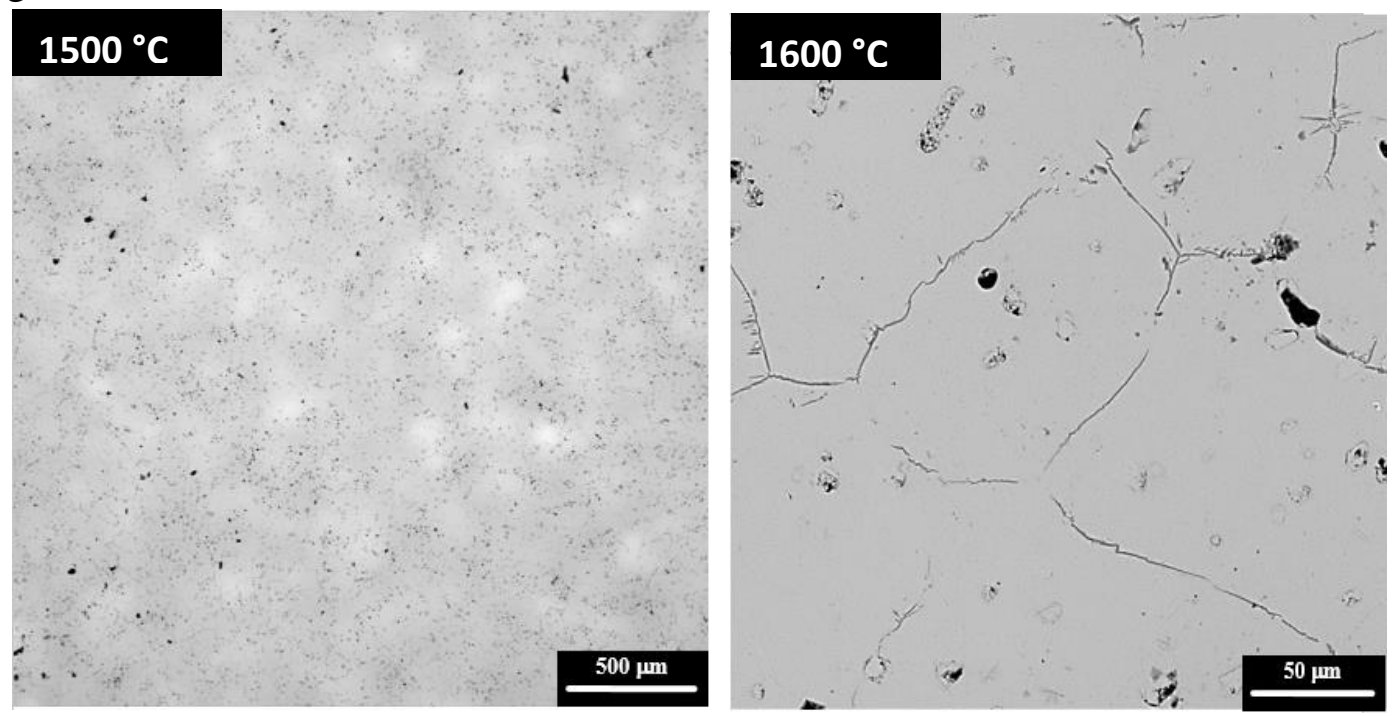

Figure 7. Microstructural development of the Ti-29Nb-13Ta-4,6Zr alloy sintered at temperatures of $1500{ }^{\circ} \mathrm{C}$ and $1600{ }^{\circ} \mathrm{C}$ obtained by SEM.

In general, the microstructural development of the TNTZ alloy was dependent on the increase in the sintering temperature and the total dissolution of $\mathrm{Ta}$ and $\mathrm{Nb}$ particles. The choice of granulometric parameters and mixing time was carefully selected to avoid the segregation of any component in the matrix or the presence of agglomerates that prevent the homogenization of the microstructure.

The microstructural evolution of the Ti-29Nb-13Ta-4,6Zr (TNTZ) based on the dissolution of the $\beta$ phase stabilizing elements during sintering was similar to that observed in the literature for the Ti-35Nb-7Zr-5Ta (TNZT) alloy [38-40]. However, the final microstructure of the TNTZ alloy after $1600{ }^{\circ} \mathrm{C}$ is composed only of phase $\beta$, without the presence of $\alpha$ phase needles close to the grain boundaries observed in the TNZT alloy. This characteristic contributes to reducing the modulus of elasticity without the need for additional thermo-mechanics treatments [40].

\subsubsection{EDS analysis.}

Compositional mapping analyzes were carried out by EDS in order to study the dissolution of elements in the TNTZ alloy during sintering. In the mapping images (Figure 8), the blue areas represent $\mathrm{Ti}$, green $\mathrm{Nb}$, red $\mathrm{Ta}$ and orange $\mathrm{Zr}$.

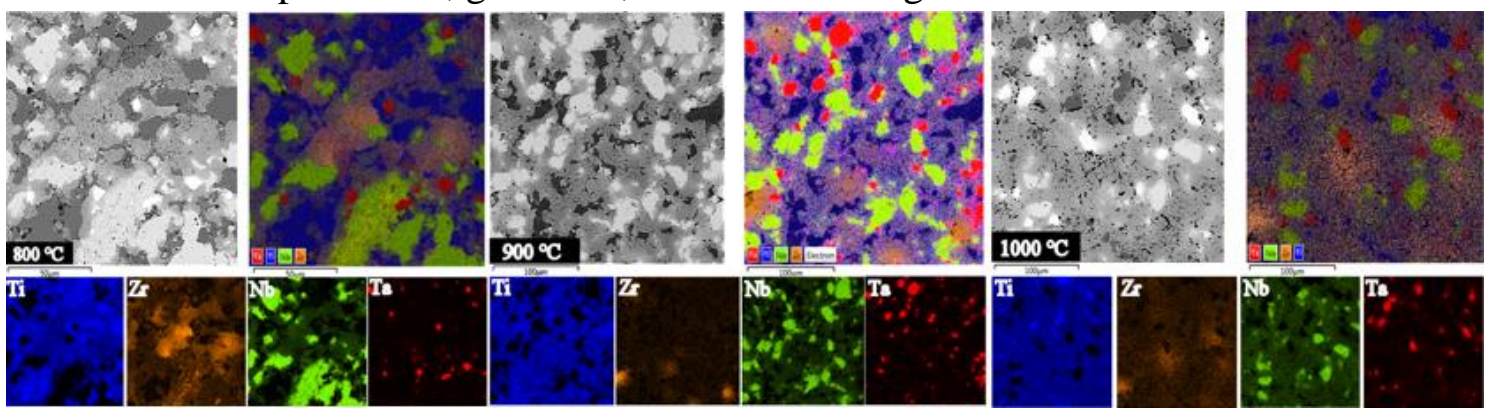

Figure 8. Compositional mapping analyzes by EDS of TNTZ sintered at 800,900 and $1000{ }^{\circ} \mathrm{C}$.

At $800^{\circ} \mathrm{C}$, the most notable fact is that areas containing $\alpha+\beta$ regions are related to Zr's dissolution. In previous studies, the literature describes the difficulty of defining the role 
of $\mathrm{Zr}$ particles due to their rapid dissolution in Ti matrix $[41,42]$. This characteristic is also observed at $900{ }^{\circ} \mathrm{C}$ and $1000^{\circ} \mathrm{C}$, which is noticeable in the intense presence of $\mathrm{Zr}$ where the $\alpha+\beta$ phase is located.

At $1200{ }^{\circ} \mathrm{C}$, it was accomplished an EDS punctual analysis (Figure 9 and Table 2). It is observed that point 1 is characterized as a Ta region, point 2 represents an $\mathrm{Nb}$-rich region, point 3 indicates a $\beta$ area close to TNTZ alloy nominal composition. Point 4 shows a two-phase area $(\alpha+\beta)$ in a region richer in Ti. This indicates that the two-phase areas at $1200{ }^{\circ} \mathrm{C}$ are formed by the increased diffusion of $\mathrm{Nb}$ and $\mathrm{Ta}$ in areas from titanium particles.

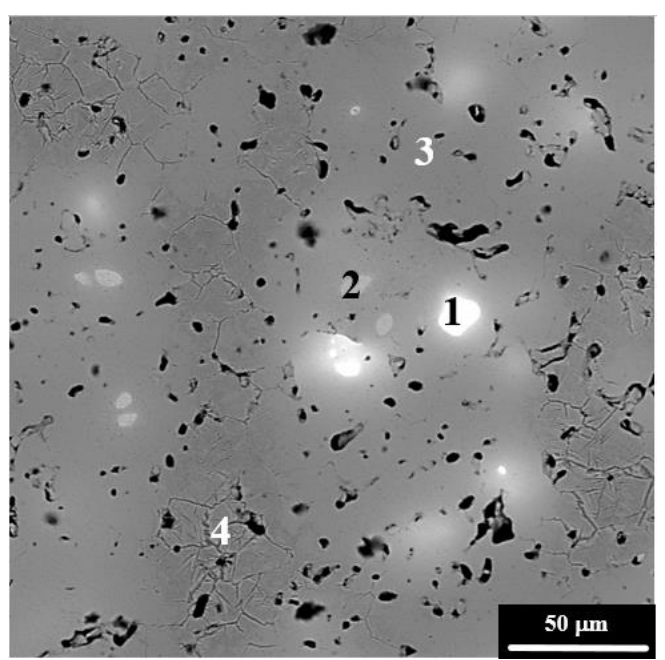

Figure 9. Sample of Ti-29Nb-13Ta-4,6Zr alloy sintered at $1200{ }^{\circ} \mathrm{C}$ in which EDS analyzes were performed at points $1,2,3$ and 4 .

Table 2. $\mathrm{Ti}, \mathrm{Nb}, \mathrm{Zr}$ and Ta contents obtained in points 1, 2, 3 and 4 analyzed by EDS in the sample of Ti-29Nb13Ta-4,6Zr alloy sintered at $1200^{\circ} \mathrm{C}$.

\begin{tabular}{c|c|c|c|c} 
Point & Ti $(\boldsymbol{\%} \mathbf{w t})$ & Nb $(\% \mathbf{w t})$ & Ta $(\% \mathbf{w t})$ & $\mathbf{Z r}(\boldsymbol{\%} \mathbf{w t})$ \\
\hline $\mathbf{1}$ & 0.1 & 0.0 & 99.6 & 0.3 \\
\hline $\mathbf{2}$ & 4.1 & 95.4 & 0.5 & 0.0 \\
\hline $\mathbf{3}$ & 53.6 & 36.4 & 6.2 & 3.9 \\
\hline $\mathbf{4}$ & 54.8 & 27.6 & 10.7 & 6.9
\end{tabular}

\subsection{Density analysis.}

The analysis of TNTZ samples indicated an increase in densification associated with an increase in sintering temperature. The low-density values at temperatures of 800 and $900{ }^{\circ} \mathrm{C}$ can be explained by the large amount of pores presented among the particles. At this stage, there was still not enough activation energy for the alloy elements to diffuse throughout the material and promote microstructural homogenization and pores amount reduction [43]. The analyzes were highly influenced by the heterogeneity of the microstructure and the elevated number of pores at lower temperatures. As the temperature increased, the diffusion mechanisms of mass transport were activated, allowing a higher interaction between the elements of the alloy, retraction and elimination of the pores [44]. The increase in density occurred gradually at a rate of approximately $2 \%$ at each temperature. At $1500{ }^{\circ} \mathrm{C}$, the TNTZ alloy had a maximum density value of $5.71 \mathrm{~g} / \mathrm{cm}^{3}$, which represented densification of $96 \%$ compared with the theoretical value (Figure 10). At $1600{ }^{\circ} \mathrm{C}$, which was the last experimental temperature, this level of density was maintained. 


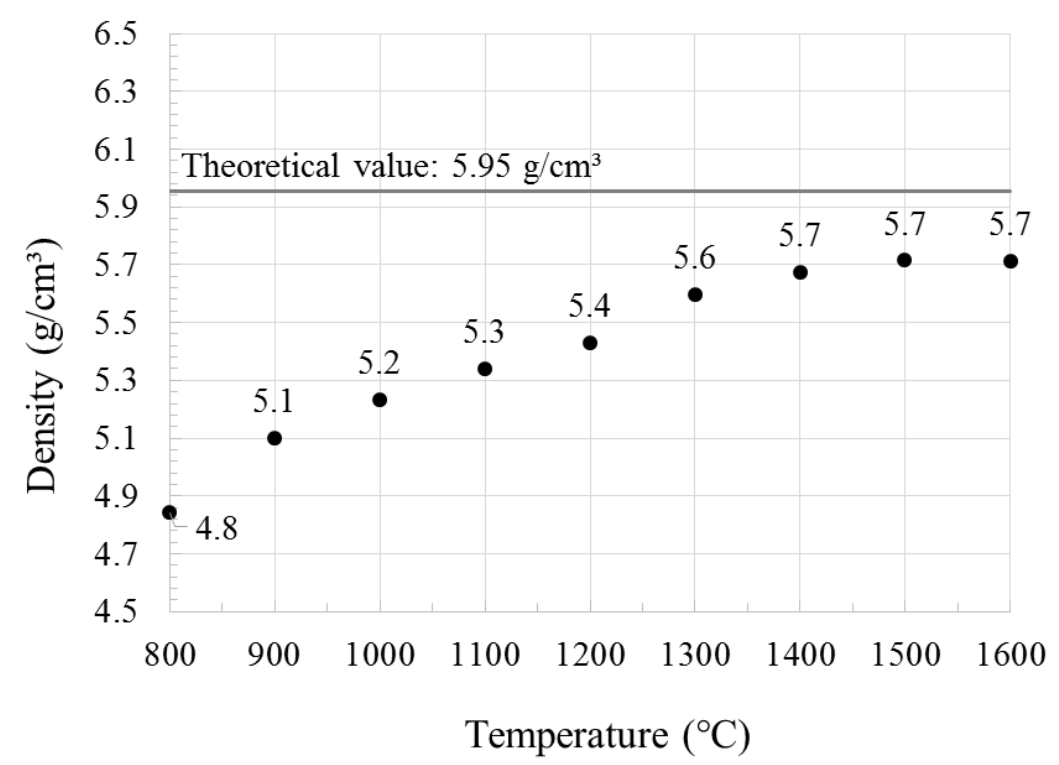

Figure 10. Density curve of Ti-29Nb-13Ta-4.6Zr alloy from $800{ }^{\circ} \mathrm{C}$ to $1600{ }^{\circ} \mathrm{C}$.

\subsection{X-ray diffraction analysis.}

The XRD analyzes of TNTZ alloy samples sintered between $800{ }^{\circ} \mathrm{C}$ to $1600{ }^{\circ} \mathrm{C}$ is shown in Figure 11. The primary peak from phase $\beta$ occurs coincidentally with the phase $\alpha$ peak in $2 \theta$ equal to 38.4 , and its identification is complex. However, the identification of the $\beta$ phase was reinforced by the presence of the secondary and ternary peaks that occur separately in $2 \theta$ equal to $69.6^{\circ}$ and $55.5^{\circ}$, respectively.

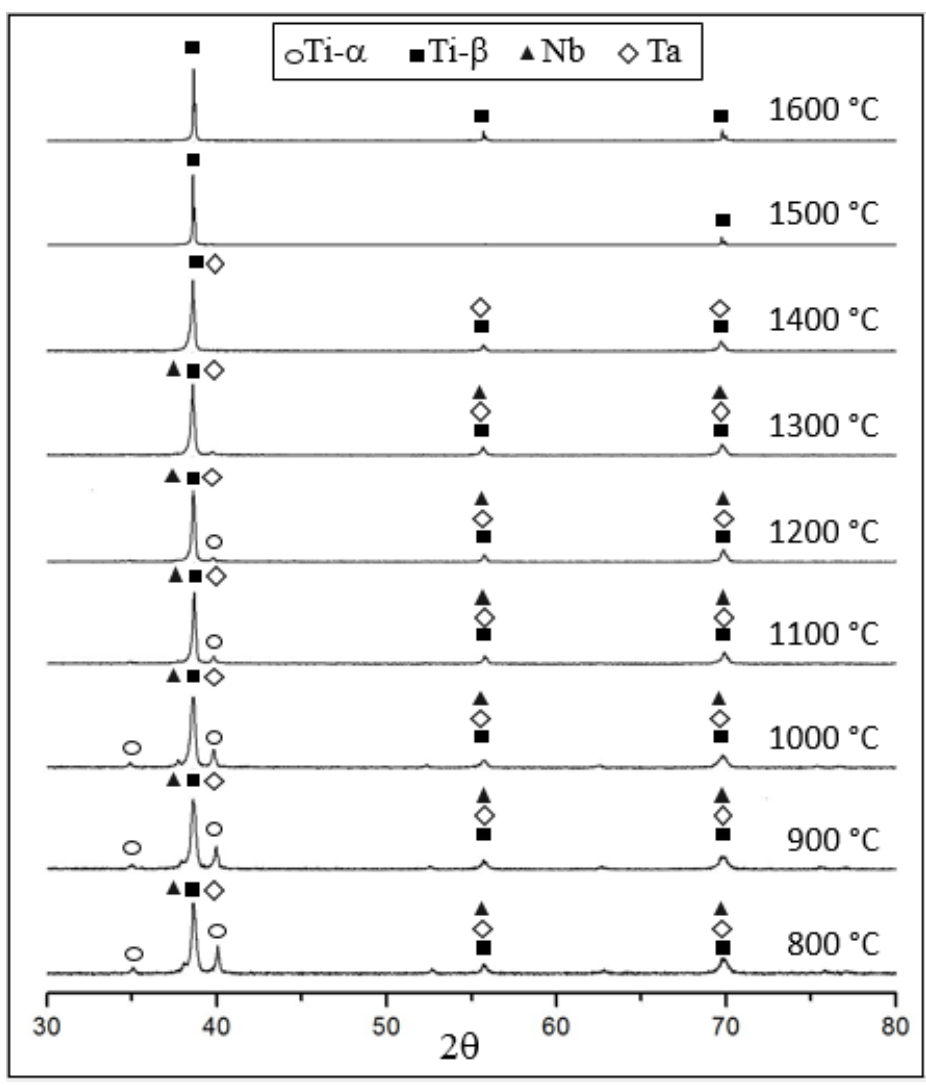

Figure 11. X-ray diffraction (XRD) patterns of Ti-29Nb-13Ta-4.6Zr alloy sintered from $800{ }^{\circ} \mathrm{C}$ to $1600{ }^{\circ} \mathrm{C}$.

$\mathrm{Nb}$ and Ta have peaks coinciding with those of phase Ti- $\beta$. Based on SEM's microstructural development, it is possible to confirm the presence of undissolved $\mathrm{Nb}$ until 
$1300{ }^{\circ} \mathrm{C}$ and Ta up to $1500{ }^{\circ} \mathrm{C}$. The most important aspect of the diffractogram interpretation lies in the tendency for a vanishment of $\alpha$ peaks with increasing sintering temperature, becoming absent from $1400{ }^{\circ} \mathrm{C}$. This indicated the stabilization of the $\beta$ phase in the alloy microstructure due to the high contents of $\beta$ stabilizers from the $\mathrm{Nb}$ and $\mathrm{Ta}$ dissolution. The XRD analysis reinforced the information obtained by SEM regarding microstructural development.

\subsection{Mechanical properties analyses.}

\subsubsection{Microhardness.}

The graph in Figure 12 illustrates the microhardness behavior of the TNTZ alloy produced by $\mathrm{P} / \mathrm{M}$. As well as density analysis, the alloy microhardness behavior tended to increase with increasing temperature. At $800{ }^{\circ} \mathrm{C}$ (initial temperature), the microhardness value was $128 \mathrm{HV}$ and $352 \mathrm{HV}$ at $1600{ }^{\circ} \mathrm{C}$ (final temperature). The increase in these values is due to the densification process and homogenization of the $\beta$ microstructure during sintering since the indentation close to pores and elements in dissolution tends to show lower values.

Haftalang et al. (2020) [37,45] studied the micro and macro mechanical properties of the metastable $\mathrm{Ti}-29 \mathrm{Nb}-14 \mathrm{Ta}-4.5 \mathrm{Zr}$ alloy holding nano-sized precipitates. The precipitates studies evaluated the influence of phases $\alpha$ and $\omega$ in the microhardness values. The samples analyzed were obtained via the hot-forged condition and were submitted to different heat treatments. The samples that presented phases $\beta+\alpha$ and $\beta+\omega$ showed microhardness values around $398 \mathrm{HV}$ and $510 \mathrm{HV}$. These values increment can be associated with the high resistance of these second phases to the local shear stress.

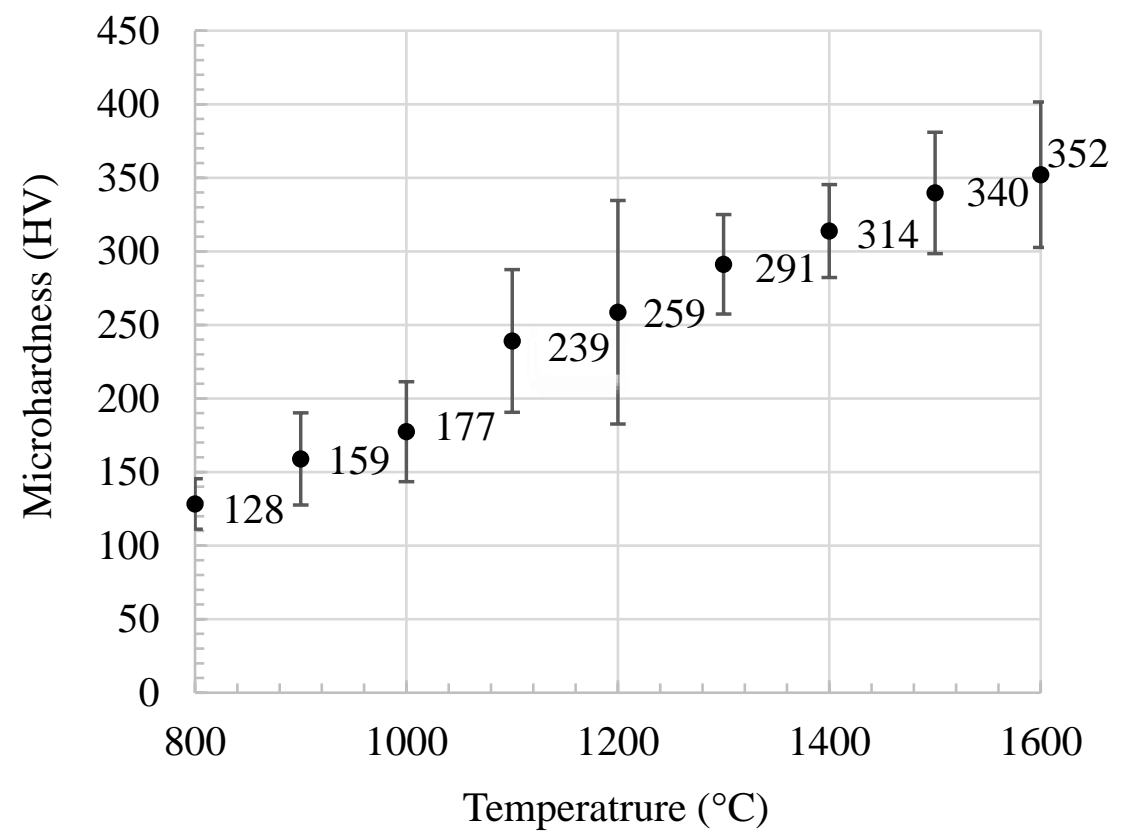

Figure 12. Microhardness curve of Ti-29Nb-13Ta-4.6Zr alloy from $800{ }^{\circ} \mathrm{C}$ to $1600{ }^{\circ} \mathrm{C}$.

\subsubsection{Compression test.}

The graph in Figure 13 shows the stress $\mathrm{x}$ deformation curve obtained in the compression test of the TNTZ alloy samples sintered at $1600{ }^{\circ} \mathrm{C}$. The elastic modulus (E) was obtained by linearizing the linear portion of the curve, which corresponds to the elastic deformation region of the material. For 6 samples tested, the average value obtained was $42 \pm$ 
$7 \mathrm{GPa}$, very close to that found in the literature for this alloy manufactured by melting techniques [16,18,46-48]. The ultimate tensile strength (UTS) showed an average value of $1018 \mathrm{MPa}$ with a standard deviation of $248 \mathrm{MPa}$, also close to the values obtained for beta alloys produced by conventional techniques [49].

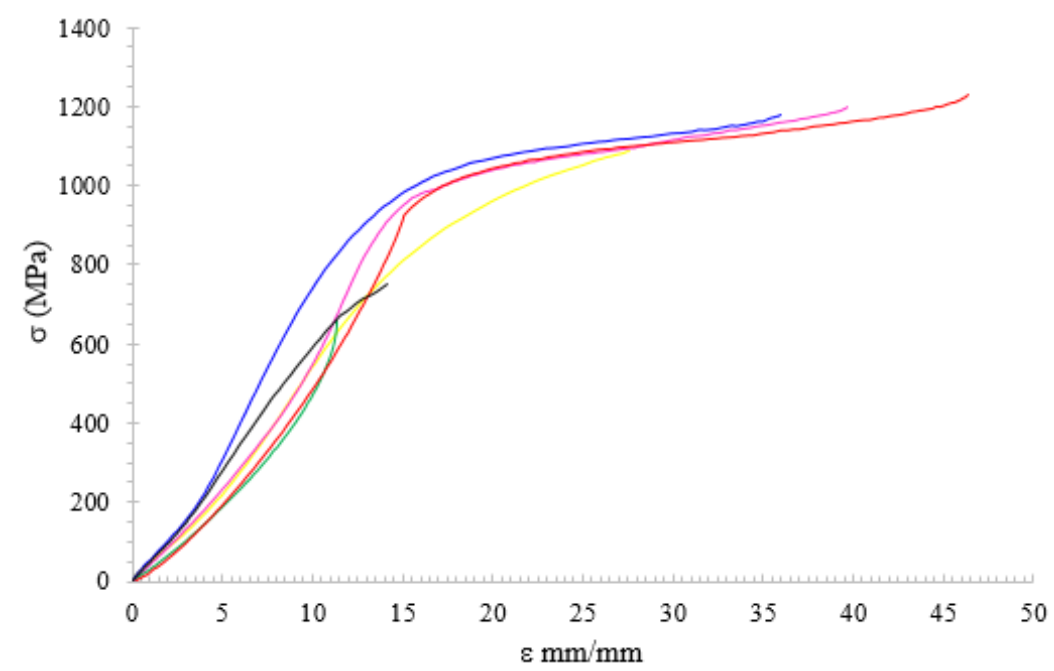

Figure 13. Compressive stress-strain curve of Ti-29Nb-13Ta-4.6Zr alloy sintered at $1600{ }^{\circ} \mathrm{C}$.

\subsubsection{Bending test.}

The flexural strength and E results were $1297 \pm 156 \mathrm{MPa}$ and $39 \pm 8 \mathrm{GPa}$, respectively. These results are superior compared to human cortical bone and other ceramic biomaterials such as $\mathrm{Al}_{2} \mathrm{O}_{3}$ and $\mathrm{ZrO}_{2}[3,50]$. Comparing the $\mathrm{E}$ result obtained with the result found in the compression test, the values present a slight difference of $8.2 \%$.

\subsection{Biological characterization of TNTZ alloy.}

\subsubsection{Microbial biofilm formation.}

The results suggest that the anti-biofilm formation outcome may have been positively influenced by the chemical composition of the TNTZ alloy and the microstructural composition constituted by the $\beta$-phase. Significative reduction in the number of viable cells in the biofilms formed by $C$. albicans and $P$. aeruginosa on TNTZ alloy was observed when compared with the T-6Al-4V alloy. A reduction of $36.86 \%$ and $60.53 \%$ was detected, respectively, as can be seen in (Figure 14). This way, the results suggest an important and promising antimicrobial activity, as these microorganisms are amongst the most common found in implant infections and are responsible for the major problems in elective and trauma surgery [51]. It is known that the formation of biofilms directly impacts the success of implant surgery because their eradication is extremely difficult and increases the probability of infection progress considerably [52].

The results obtained in this research are in accordance to a previous study that evaluated different Ti compositions on biofilm formation, and the second better antibiofilm activity was shown by Ti-Zr [53]. According to Fellah et al. (2020) studies, the nanostructure and microstructure could influence the antimicrobial property [54-57]. According to the literature, the improvement of $\beta$-alloys with addiction of elements as $\mathrm{Nb}, \mathrm{Zr}, \mathrm{Mo}$, Ta, or $\mathrm{Sn}$ may influence the biological properties, such as biocompatibility [58]. The TNTZ alloy used in this study has 
$\beta$-phase as major composition and the presence of $\beta$-phase with elements as $\mathrm{Ta}, \mathrm{Zr}$ could have influenced the anti-biofilm results.

In this study, no differences in the biofilm formation by $S$. aureus were detected ( $>0.05$ ). Differences in the responses to the materials of different microbial groups have already been detected previously. Szymczyk-Ziółkowska et al. (2020), observed that S. aureus formed a significatively more robust biofilm on Ti-6Al-4V surfaces than $P$. aeruginosa and $C$. albicans [55].

Another interesting observation was the notably more profuse biofilm formed by $P$. aeruginosa when compared to $S$. aureus and $C$. albicans. This difference can be related to the differential ability of different microbial species to adhere to the material's surface. According to Ferraris et al. (2018), the presence of the outer membrane in Gram-negative bacteria may allow a more fluidic interaction with the nano-irregularities of the material and favor bacterial adherence [56].

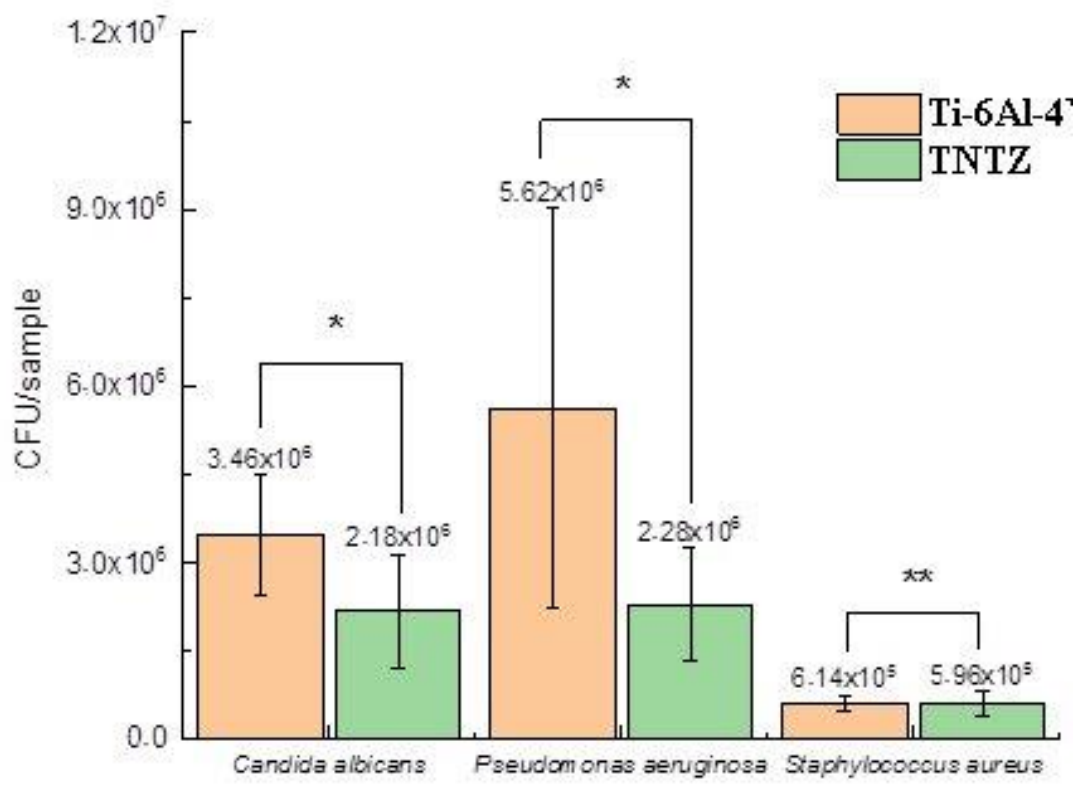

Figure 14. Viability of biofilms formed by Candida albicans, Pseudomonas aeruginosa and Staphylococcus aureus on TNTZ and T-6Al-4V alloys specimens. *Statistically significant differences $(\mathrm{p}=0,05)$. **not statistically significant.

\subsubsection{In vitro cytotoxicity on Vero cells.}

The evaluation of cytotoxicity is an important step for proving the biocompatibility of a material. Among the most used alloys, Ti-6Al-4V is the most employed titanium alloy used as a biomaterial. However, it contains vanadium in its composition that has been considered highly cytotoxic. In search of low cytotoxicity, the TNTZ alloy becomes interesting due to the absence of this compound. In the researches, the viability of TNTZ was analyzed using Vero cells that are a lineage highly recommended for studies of cytotoxicity and for cell substratum interactions for biomaterials research [59]. For this research, cytotoxicity of TNTZ alloy was also analyzed with Vero cells and the results for the concentrations of $50 \%$, are shown in Figure 15. TNTZ alloy group showed a cell viability of $73.6 \%$ and according to the classification adopted, TNTZ alloy was sorted as slightly cytotoxic [34]. Thus, TNTZ alloy appears to have an advantage as it does not contain vanadium in its composition 
Previously, a cell viability study accomplished by Costa et al. (2019) [60] showed that vanadium ions were released into the cell culture medium. Hence, it has been suggested that the prolonged presence of this material for long periods can be potentially dangerous for the body environment.

Chandar et al. 2017 [61] analyzed the cytotoxicity of alloy Ti-6Al-4V and Ti pure on human gingival fibroblast. The cells were treated with different doses $(5-100 \mu 1$ add in the culture medium) and showed a $13 \%$ to $17 \%$ reduction in cell viability after $48 \mathrm{~h}$ and $72 \mathrm{~h}$, respectively, for the alloy Ti-6Al-4V. The presence of vanadium reduces cell viability since when analyzing pure titanium, the viability was above $90 \%$.

Niinomi et al., 2003 [19], evaluated the cytotoxicity of TNTZ, Ti-6Al-4V and pure Ti alloys. The extracts were exposed to the alloys for 7 or 14 days and the L929 cells were then exposed to these solutions for 2 days. The TNTZ alloy was classified as non-cytotoxic, similar to Ti pure. The Ti-6Al-4V alloy had a cell viability of around $70 \%$.

Therefore, the TNTZ alloy did not induce a significant cytotoxic effect and would not have a clinically important impact. In this way, TNTZ can be considered for biomedical applications.

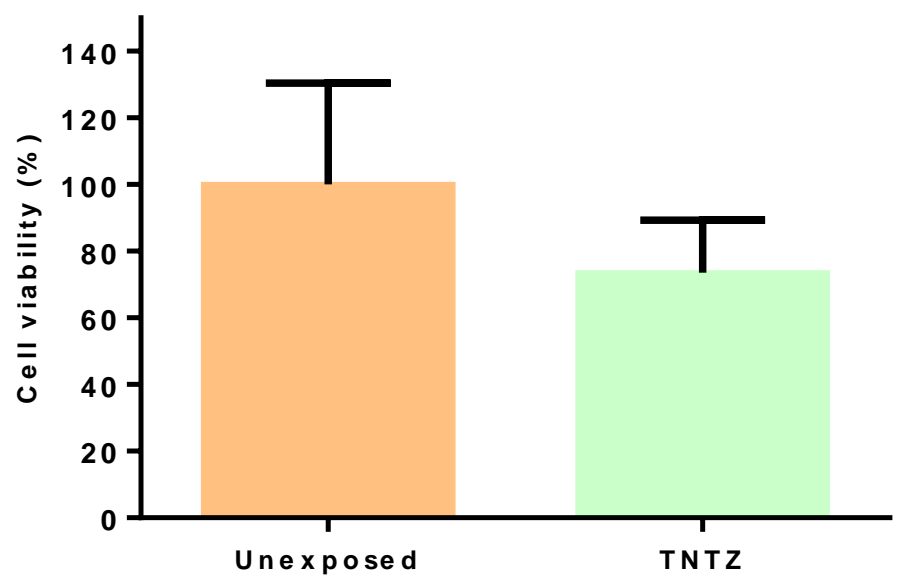

Figure 15. Vero cells viability after $24 \mathrm{~h}(\mathrm{n}=9)$.

\subsubsection{In vivo biocompatibility test.}

When there is a biomaterial implant, a three-phase process occurs that includes blood/material interaction, inflammation (acute followed by chronic), and granulation tissue formation [62]. The inflammation normally lasts not more than two weeks and, when there is no infection, a fibrous capsule is formed [62]. One of the first signs to be observed is the absence of liquid on the interface implant/soft tissue (seroma), which could prevent implant bond to soft tissues, an important factor to repair, especially in reconstructions and facial contouring implants [63].

The histopathologic analyses showed that 14 days after the implantation of TNTZ alloy specimens, tissue remodeling can be noticed in the implant area, both in the epithelium and subepithelial regions. The epithelium is slightly hyperplasic and the subepithelial region reveals several active fibroblasts and a diffuse mild inflammatory infiltrate, composed mainly by macrophages. These features can also be observed in deeper sections of the tissue, where several active fibroblasts, some macrophages, plasmocytes and rare lymphocytes can be observed in the area around the implant as well as sparse giant cells. In resume, there is mild inflammation, chronic, with the initial formation of granulation tissue and an initial formation 
of a fibrous capsule around the implant, expected signs for the period when there is no material rejection. No signs of necrosis could be found.

The presence of giant cells is common for the two-week analyzed period as well as capsule formation and granulation tissue, and it is in accordance with other studies in the literature that evaluated biocompatible alloys [64-67], as it is a foreign body. Erdmann et al. (2010) and Elkaim et al. (2019) [64,67] found giant cells in periods longer than two weeks with no other signs of rejection.

Complete tissue repair could be observed in the animal submitted to sham procedure (control) after 14 days. The epidermis and dermis are well-delimited, without inflammatory infiltrate. The connective tissue is dense, with few fibrocytes and rare fibroblasts. Sebaceous glands and hair follicles can be observed. Muscle and sub-muscle layers are intact. The described picture is totally expected as well, though a surgical sham procedure has been done once the blood/material phase is absent and the local injury is smaller.

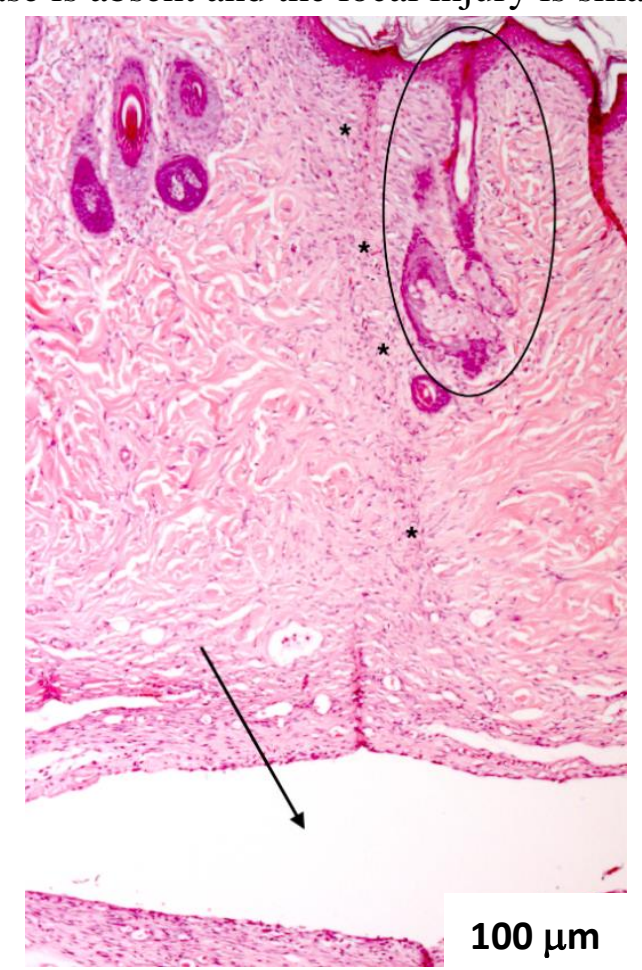

Figure 16. Tissue remodeling from the epithelium to the implant area evidencing mild inflammation surrounding the incision area $(*)$ as well as around the implant area (arrow). A pilus follicle is evidenced (circle).

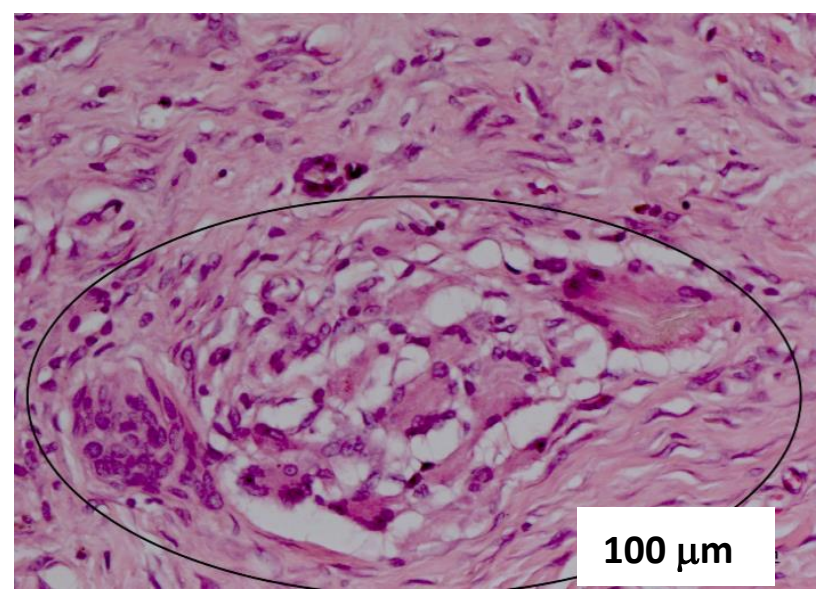

Figure 17. A group of giant cells can be observed (circle) in the connective tissue, surrounded by macrophages, lymphocytes and rare neutrophils. 
In short, inflammatory responses due to the repair processes could be observed after implanting TNTZ alloy specimens. The absence of intense polymorphonuclear inflammatory infiltrate, necrosis or edema, and no foreign body reaction are evidence of biocompatibility. Studies carried out with implants made of 316L stainless steel show that this material tends to form fibrous capsular tissue when implanted in subcutaneous tissue [1]. For this material, surface modification processing is required to improve the biocompatibility properties [68]. Based on the histopathologic findings associated with low cytotoxicity, it can be suggested that the TNTZ alloy specimens are biocompatible.

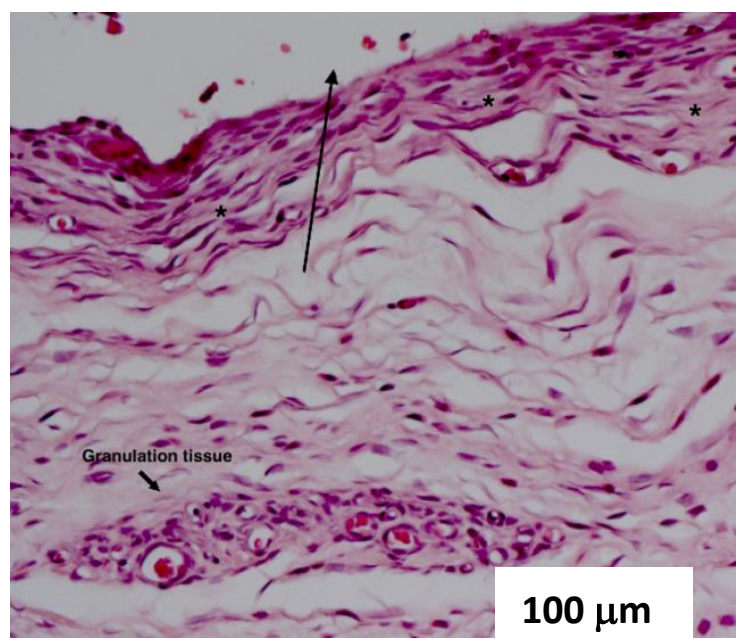

Figure 18. Area of capsule formation ${ }^{*}$ ) can be seen as well as areas of granulation tissue around all the capsule. Plus, active fibroblasts and inflammatory cells are dispersed in the tissue.

\section{Conclusions}

In the present study, the $\beta$-type TNTZ alloy has been fabricated in a relatively costeffective method from hydride powders. The effect of the processing on the microstructure, mechanical properties, and biocompatible behavior was investigated and led to the following conclusions:

The microstructural development indicated a tendency to exhibit a $\beta$ phase with increasing sintering temperature. The microstructural homogenization of the alloy is obtained after the total dissolution of the Ta particles that only occur at $1600{ }^{\circ} \mathrm{C}$;

The microhardness and density values tended to grow as the temperature increased. These results were related to the dissolution of the alloying elements in the titanium matrix and the presence of pores;

The mechanical properties analyzed by compression and bending tests showed low values of the modulus of elasticity which may contribute to avoid the phenomenon of stress shield in bone tissue repair implants;

The microbiological tests pointed out that TNTZ alloy was less prone to the adherence of $C$. albicans and $P$. aeruginosa than the control alloy commonly used as raw material in implants;

TNTZ alloy showed low cytotoxicity to Vero cells;

The in vivo analysis of subcutaneous implantation indicated that there was no tissue rejection process, suggesting that the TNZT alloy implants produced by tested P/M are biocompatible;

Combining relatively low-cost powders, compaction techniques with high productivity, homogeneous microstructure, good mechanical properties, low modulus of elasticity, and high 
biocompatibility can make the production of the alloy $\mathrm{Ti}-29 \mathrm{Nb}-13 \mathrm{Ta}-4,6 \mathrm{Zr}$ per $\mathrm{P} / \mathrm{M}$ more attractive in biomedical applications.

\section{Funding}

This research was funded by Coordenação de Aperfeiçoamento de Pessoal de Nível Superior Brasil (CAPES), grant number 88882.180787/2018-01.

\section{Acknowledgments}

The authors wish to thank Instituto Nacional de Pesquisas Espaciais (INPE) and Instituto de Aeronáutica e Epaço (IAE) for the reagents used in this research and for providing the facilities, funding and equipment for the experiments

\section{Conflicts of Interest}

The authors declare no conflict of interest and the funders had no role in the study's design, in the collection, analyses, or interpretation of data, in the writing of the manuscript, or in the decision to publish the results.

\section{References}

1. Chen, Q.; Thouas, G.A. Metallic implant biomaterials. Mater. Sci. Eng. R Reports 2015, 87, 1-57, https://doi.org/10.1016/j.mser.2014.10.001.

2. Niinomi, M. Titanium Alloys with High Biological and Mechanical Biocompatibility. In Proceedings of the Biomaterials in Asia; WORLD SCIENTIFIC, 2008; 269-291.

3. Li, Y.; Yang, C.; Zhao, H.; Qu, S.; Li, X.; Li, Y. New Developments of Ti-Based Alloys for Biomedical Applications. Materials (Basel). 2014, 7, 1709-1800, https://doi.org/10.3390/ma7031709.

4. Niinomi, M.; Nakai, M.; Hieda, J. Development of new metallic alloys for biomedical applications. Acta Biomater. 2012, 8, 3888-3903, https://doi.org/10.1016/j.actbio.2012.06.037.

5. Gepreel, M.A.; Niinomi, M. Biocompatibility of Ti-alloys for long-term implantation. J. Mech. Behav. Biomed. Mater. 2013, 20, 407-415, https://doi.org/10.1016/j.jmbbm.2012.11.014.

6. Karre, R.; Dey, S.R. Progress in Development of Beta Titanium Alloys for Biomedical Applications. In Reference Module in Materials Science and Materials Engineering; Elsevier, 2019; 1-18.

7. do Prado, R.F.; Esteves, G.C.; Santos, E.L.D.S.; Bueno, D.A.G.; Cairo, C.A.A.; Vasconcellos, L.G.O.D.; Sagnori, R.S.; Tessarin, F.B.P.; Oliveira, F.E.; Oliveira, L.D.D.; Villaça-Carvalho, M.F.L.; Henriques, V.A.R.; Carvalho, Y.R.; De Vasconcellos, L.M.R. In vitro and in vivo biological performance of porous Ti alloys prepared by powder metallurgy. PLoS One 2018, 13, e0196169, https://doi.org/10.1371/journal.pone.0196169.

8. Weng, W.; Biesiekierski, A.; Li, Y.; Wen, C. Effects of selected metallic and interstitial elements on the microstructure and mechanical properties of beta titanium alloys for orthopedic applications. Materialia 2019, 6, 100323, https://doi.org/10.1016/j.mtla.2019.100323.

9. Niinomi, M.; Liu, Y.; Nakai, M.; Liu, H.; Li, H. Biomedical titanium alloys with Young's moduli close to that of cortical bone. Regen. Biomater. 2016, 3, 173-185, https://doi.org/10.1093/rb/rbw016.

10. Li, J.; Qin, L.; Yang, K.; Ma, Z.; Wang, Y.; Cheng, L.; Zhao, D. Materials evolution of bone plates for internal fixation of bone fractures: A review. J. Mater. Sci. Technol. 2020, 36, 190-208, https://doi.org/10.1016/j.jmst.2019.07.024.

11. Chicardi, E.; Gutiérrez-González, C.F.; Sayagués, M.J.; García-Garrido, C. Development of a novel TiNbTa material potentially suitable for bone replacement implants. Mater. Des. 2018, 145, 88-96, https://doi.org/10.1016/j.matdes.2018.02.042.

12. Bai, Y.; Deng, Y.; Zheng, Y.; Li, Y.; Zhang, R.; Lv, Y.; Zhao, Q.; Wei, S. Characterization, corrosion behavior, cellular response and in vivo bone tissue compatibility of titanium-niobium alloy with low Young's modulus. Mater. Sci. Eng. C 2016, 59, 565-576, https://doi.org/10.1016/j.msec.2015.10.062.

13. Kalaie, M.A.; Zarei-Hanzaki, A.; Ghambari, M.; Dastur, P.; Málek, J.; Farghadany, E. The effects of second 
phases on superelastic behavior of TNTZ bio alloy. Mater. Sci. Eng. A 2017, 703, 513-520, https://doi.org/10.1016/j.msea.2017.07.053.

14. Stráský, J.; Janeček, M.; Harcuba, P.; Preisler, D.; Landa, M. Biocompatible beta-Ti alloys with enhanced strength due to increased oxygen content. In Titanium in Medical and Dental Applications; Woodhead Publishing, 2018; 371-392.

15. Hagihara, K.; Nakano, T. Experimental clarification of the cyclic deformation mechanisms of $\beta$-type Ti-NbTa-Zr-alloy single crystals developed for the single-crystalline implant. Int. J. Plast. 2017, 98, 27-44, https://doi.org/10.1016/j.ijplas.2017.06.006.

16. Liu, H.; Niinomi, M.; Nakai, M.; Obara, S.; Fujii, H. Improved fatigue properties with maintaining low Young's modulus achieved in biomedical beta-type titanium alloy by oxygen addition. Mater. Sci. Eng. A 2017, 704, 10-17, https://doi.org/10.1016/j.msea.2017.07.078.

17. do Prado, R.F.; Rabêlo, S.B.; de Andrade, D.P.; Nascimento, R.D.; Henriques, V.A.R.; Carvalho, Y.R.; Cairo, C.A.A.; de Vasconcellos, L.M.R. Porous titanium and $\mathrm{Ti}-35 \mathrm{Nb}$ alloy: effects on gene expression of osteoblastic cells derived from human alveolar bone. J. Mater. Sci. Mater. Med. 2015, 26, 259, https://doi.org/10.1007/s10856-015-5594-0.

18. Kunčická, L.; Kocich, R.; Lowe, T.C. Advances in metals and alloys for joint replacement. Prog. Mater. Sci. 2017, 88, 232-280, https://doi.org/10.1016/j.pmatsci.2017.04.002.

19. Niinomi, M. Fatigue performance and cyto-toxicity of low rigidity titanium alloy, Ti-29Nb-13Ta-4.6Zr. Biomaterials 2003, 24, 2673-2683, https://doi.org/10.1016/S0142-9612(03)00069-3.

20. Takematsu, E.; Noguchi, K.; Kuroda, K.; Ikoma, T.; Niinomi, M.; Matsushita, N. In vivo osteoconductivity of surface modified Ti-29Nb-13Ta-4.6Zr alloy with low dissolution of toxic trace elements. PLoS One 2018, 13, e0189967, https://doi.org/10.1371/journal.pone.0189967.

21. Lee, Y.S.; Niinomi, M.; Nakai, M.; Narita, K.; Cho, K. Predominant factor determining wear properties of $\beta$ type and $(\alpha+\beta)$-type titanium alloys in metal-to-metal contact for biomedical applications. J. Mech. Behav. Biomed. Mater. 2015, 41, 208-220, https://doi.org/10.1016/j.jmbbm.2014.10.005.

22. Liu, J.; Chang, L.; Liu, H.; Li, Y.; Yang, H.; Ruan, J. Microstructure, mechanical behavior and biocompatibility of powder metallurgy $\mathrm{Nb}-\mathrm{Ti}-\mathrm{Ta}$ alloys as biomedical material. Mater. Sci. Eng. C 2017, 71, 512-519, https://doi.org/10.1016/j.msec.2016.10.043.

23. Ahamed, R.; Ghomashchi, R.; Xie, Z.; Chen, L. Powder Metallurgy Synthesis of Heusler Alloys: Effects of Process Parameters. Materials (Basel). 2019, 12, 1596, https://doi.org/10.3390/ma12101596.

24. Alshammari, Y.; Yang, F.; Bolzoni, L. Mechanical properties and microstructure of Ti-Mn alloys produced via powder metallurgy for biomedical applications. J. Mech. Behav. Biomed. Mater. 2019, 91, 391-397, https://doi.org/10.1016/j.jmbbm.2018.12.005.

25. Alshammari, Y.; Jia, M.; Yang, F.; Bolzoni, L. The effect of $\alpha+\beta$ forging on the mechanical properties and microstructure of binary titanium alloys produced via a cost-effective powder metallurgy route. Mater. Sci. Eng. A 2020, 769, 138496, https://doi.org/10.1016/j.msea.2019.138496.

26. Bolzoni, L.; Ruiz-Navas, E.M.; Gordo, E. Feasibility study of the production of biomedical Ti-6Al-4V alloy by powder metallurgy. Mater. Sci. Eng. C 2015, 49, 400-407, https://doi.org/10.1016/j.msec.2015.01.043.

27. Bolzoni, L.; Ruiz-Navas, E.M.; Gordo, E. Quantifying the properties of low-cost powder metallurgy titanium alloys. Mater. Sci. Eng. A 2017, 687, 47-53, https://doi.org/10.1016/j.msea.2017.01.049.

28. Qian, M.; Froes, F.H. Titanium Powder Metallurgy. Science, Technology and Applications; ButterworthHeinemann, 2015.

29. Savvakin, D.H.; Humenyak, M.M.; Matviichuk, M. V.; Molyar, O.H. Role of Hydrogen in the Process of Sintering of Titanium Powders. Mater. Sci. 2012, 47, 651-661, https://doi.org/10.1007/s11003-012-9440-y.

30. ASTM E9-19. Standard Test methods of compression testing of metallic materials at room temperature. ASTM International: United Stated of America, 2019; 19;.

31. ASTM E855-8. Standard test methods for bend testing of metallic flat materials for spring applications involving static loading. 2013; 9.

32. KIDO, H.W. Biocompatibilidade da vitrocerâmica bioativa (Biosilicato®): análises in vitro e in vivo, Universidade de São Carlos, 2011.

33. Sletten, G.B.G.; Dahl, J.E. Cytotoxic effects of extracts of compomers. Acta Odontol. Scand. 1999, 57, 316322, https://doi.org/10.1080/000163599428544.

34. 10993-1, A.B.D.N.T.N.I. Avaliação biológica de produtos para saúde: avaliação e ensaio dentro de um processo de gerenciamento de risco; Rio de Janeiro, 2013.

35. Polmear, I.; StJohn, D.; Nie, J.; Qian, M. Titanium Alloys. In Light Alloys; Butterworth-Heinemann, 2017; 
$369-460$.

36. Quadros, F. de F.; Kuroda, P.A.B.; Sousa, K. dos S.J.; Donato, T.A.G.; Grandini, C.R. Preparation, structural and microstructural characterization of Ti-25Ta-10Zr alloy for biomedical applications. J. Mater. Res. Technol. 2019, 8, 4108-4114, https://doi.org/10.1016/j.jmrt.2019.07.020.

37. German, R. Sintering: from Empirical Observations to Scientific Principles; Butterworth-Heinmann, 2014.

38. Taddei, E.B.; Henriques, V.A.R.; Silva, C.R.M.; Cairo, C.A.A. Production of new titanium alloy for orthopedic implants. Mater. Sci. Eng. C 2004, 24, 683-687, https://doi.org/10.1016/j.msec.2004.08.011.

39. Taddei, E.B.; Henriques, V.A.R.; Silva, C.R.M.; Cairo, C.A.A. Characterization of Ti-35Nb-7Zr-5Ta alloy produced by Powder Metallurgy. Mater. Sci. Forum 2005, 499, 34-39, https://doi.org/10.4028/www.scientific.net/MSF.498-499.34.

40. Taddei, E.B.; Henriques, V.A.R.; Silva, C.R.M.; Cairo, C.A.A. Densification and Microstructural Behaviour on the Sintering of Blended Elemental Ti-35Nb-7Zr-5Ta Alloy. Mater. Sci. Forum 2006, 530-531, 341-346, https://doi.org/10.4028/www.scientific.net/MSF.530-531.341.

41. Sakaguchi, N.; Mitsuo, N.; Akahori, T.; Saito, T.; Furuta, T. Effects of Alloying Elements on Elastic Modulus of Ti-Nb-Ta-Zr System Alloy for Biomedical Applications. Mater. Sci. Forum 2004, 449-452, 1269-1272, https://doi.org/10.4028/www.scientific.net/MSF.449-452.1269.

42. Weiss, I.; Semiatin, S.L. Thermomechanical processing of alpha titanium alloys - An overview. Mater. Sci. Eng. A 1998, 263, 243-256, https://doi.org/10.1016/S0921-5093(97)00783-1.

43. Henriques, V.A.R.; Galvani, E.T.; Petroni, S.L.G.; Paula, M.S.M.; Lemos, T.G. Production of Ti - $13 \mathrm{Nb}-$ $13 \mathrm{Zr}$ alloy for surgical implants by powder metallurgy. J Mater Sci 2010, 45, 5844-5850, https://doi.org/10.1007/s10853-010-4660-8.

44. Haftlang, F.; Zarei-Hanzaki, A.; Abedi, H.R.; Kalaei, M.A.; Nemecek, J.; Málek, J. Room-temperature micro and macro mechanical properties of the metastable $\mathrm{Ti}-29 \mathrm{Nb}-14 \mathrm{Ta}-4.5 \mathrm{Zr}$ alloy holding nano-sized precipitates. Mater. Sci. Eng. A 2020, 771, 138583, https://doi.org/10.1016/j.msea.2019.138583.

45. Haftlang, F.; Zarei-Hanzaki, A.; Abedi, H.R. The effect of nano-size second precipitates on the structure, apatite-inducing ability and in-vitro biocompatibility of Ti-29Nb-14Ta-4.5Zr alloy. Mater. Sci. Eng. C 2020, 109, 110561, https://doi.org/10.1016/j.msec.2019.110561.

46. Elmay, W.; Laheurte, P.; Eberhardt, A.; Bolle, B.; Gloriant, T.; Patoor, E.; Prima, F.; Laille, D.; Castany, P.; Wary, M. Stability and elastic properties of Ti-alloys for biomedical application designed with electronic parameters. EPJ Web Conf. 2010, 6, https://doi.org/10.1051/epjconf/20100629002.

47. Besse, M.; Castany, P.; Gloriant, T. Mechanisms of deformation in gum metal TNTZ-O and TNTZ titanium alloys: A comparative study on the oxygen influence. Acta Mater. 2011, 59, 5982-5988, https://doi.org/10.1016/j.actamat.2011.06.006.

48. Tane, M.; Akita, S.; Nakano, T.; Hagihara, K.; Umakoshi, Y.; Niinomi, M.; Nakajima, H. Peculiar elastic behavior of $\mathrm{Ti}-\mathrm{Nb}-\mathrm{Ta}-\mathrm{Zr}$ single crystals. Acta Mater. 2008, 56, 2856-2863, https://doi.org/10.1016/j.actamat.2008.02.017.

49. Long, M.; Rack, H.J. Titanium alloys in total joint replacement-a materials science perspective. Biomaterials 1998, 19, 1621-1639, https://doi.org/10.1016/S0142-9612(97)00146-4. .

50. Yang, L. Orthopedic nanoceramics. In Nanotechnology-Enhanced Orthopedic Materials; Woodhead Publishing, 2015; 49-75.

51. Pijls, B.G.; Sanders, I.M.J.G.; Kuijper, E.J.; Nelissen, R.G.H.H. Non-contact electromagnetic induction heating for eradicating bacteria and yeasts on biomaterials and possible relevance to orthopaedic implant infections. Bone Joint Res. 2017, 6, 323-330, https://doi.org/10.1302/2046-3758.65.BJR-2016-0308.R1.

52. Hickok, N.J.; Shapiro, I.M. Immobilized antibiotics to prevent orthopaedic implant infections. Adv. Drug Deliv. Rev. 2012, 64, 1165-1176, https://doi.org/10.1016/j.addr.2012.03.015.

53. Chen, S.; Tsoi, J.K.H.; Tsang, P.C.S.; Park, Y.-J.; Song, H.-J.; Matinlinna, J.P. Candida albicans aspects of binary titanium alloys for biomedical applications. Regen. Biomater. 2020, 7, 213-220, https://doi.org/10.1093/rb/rbz052.

54. Carobolante, J.P.A.; Pereira, C.A.; Dias-Netipanyj, M.F.; Popat, K.C.; Claro, A.P.R.A. Cell and BacteriaBaterial Interactions on the Ti10Mo8Nb Alloy After Surface Modification. Mater. Res. 2018, 21, 3-7, https://doi.org/10.1590/1980-5373-mr-2017-0508.

55. Szymczyk-Ziółkowska, P.; Hoppe, V.; Rusińska, M.; Gąsiorek, J.; Ziółkowski, G.; Dydak, K.; Czajkowska, J.; Junka, A. The Impact of EBM-Manufactured Ti6A14V ELI Alloy Surface Modifications on Cytotoxicity toward Eukaryotic Cells and Microbial Biofilm Formation. Materials (Basel). 2020, 13, 2822, https://doi.org/10.3390/ma13122822. 
56. Ferraris, S.; Warchomicka, F.; Iranshahi, F.; Rimondini, L.; Cochis, A.; Spriano, S. Electron Beam Structuring of Ti6Al4V: New Insights on the Metal Surface Properties Influencing the Bacterial Adhesion. Materials (Basel). 2020, 13, 409, https://doi.org/10.3390/ma13020409.

57. Fellah, M.; Hezil, N.; Touhami, M.Z.; AbdulSamad, M.; Obrosov, A.; Bokov, D.O.; Marchenko, E.; Montagne, A.; Alain, I.; Alhussein, A. Structural, tribological and antibacterial properties of $(\alpha+\beta)$ based tialloys for biomedical applications. J. Mater. Res. Technol. 2020, 9, 14061-14074, https://doi.org/10.1016/j.jmrt.2020.09.118.

58. Ureña, J.; Tejado, E.; Pastor, J.Y.; Velasco, F.; Tsipas, S.; Jiménez-Morales, A.; Gordo, E. Role of betastabilizing elements on the microstructure and mechanical properties evolution of modified PM Ti surfaces designed for biomedical applications. Powder Metall. 2018, 61, 90-99, https://doi.org/10.1080/00325899.2018.1426185.

59. Donato, T.A.G.; de Almeida, L.H.; Nogueira, R.A.; Niemeyer, T.C.; Grandini, C.R.; Caram, R.; Schneider, S.G.; Santos, A.R. Cytotoxicity study of some Ti alloys used as biomaterial. Mater. Sci. Eng. C 2009, 29, 1365-1369, https://doi.org/10.1016/j.msec.2008.10.021.

60. Costa, B.C.; Tokuhara, C.K.; Rocha, L.A.; Oliveira, R.C.; Lisboa-Filho, P.N.; Costa Pessoa, J. Vanadium ionic species from degradation of Ti-6Al-4V metallic implants: In vitro cytotoxicity and speciation evaluation. Mater. Sci. Eng. C 2019, 96, 730-739, https://doi.org/10.1016/j.msec.2018.11.090.

61. Chandar, S.; Kotian, R.; Madhyastha, P.; Kabekkodu, S.; Rao, P. In vitro evaluation of cytotoxicity and corrosion behavior of commercially pure titanium and Ti-6Al-4V alloy for dental implants. J. Indian Prosthodont. Soc. 2017, 17, 35-40, https://doi.org/10.4103/0972-4052.197936.

62. Anderson, J.M.; Rodriguez, A.; Chang, D.T. Foreign body reaction to biomaterials. Semin. Immunol. 2008, 20, 86-100, https://doi.org/10.1016/j.smim.2007.11.004.

63. Zigterman, B.G.R.; Van den Borre, C.; Braem, A.; Mommaerts, M.Y. Titanium surface modifications and their soft-tissue interface on nonkeratinized soft tissues-A systematic review (Review). Biointerphases 2019, 14, 040802, https://doi.org/10.1116/1.5113607.

64. Erdmann, N.; Bondarenko, A.; Hewicker-Trautwein, M.; Angrisani, N.; Reifenrath, J.; Lucas, A.; MeyerLindenberg, A. Evaluation of the soft tissue biocompatibility of $\mathrm{MgCa} 0.8$ and surgical steel 316L in vivo: a comparative study in rabbits. Biomed. Eng. Online 2010, 9, 63, https://doi.org/10.1186/1475-925X-9-63.

65. Miura, C.; Shimizu, Y.; Imai, Y.; Mukai, T.; Yamamoto, A.; Sano, Y.; Ikeo, N.; Isozaki, S.; Takahashi, T.; Oikawa, M.; Kumamoto, H.; Tachi, M. In vivo corrosion behaviour of magnesium alloy in association with surrounding tissue response in rats. Biomed. Mater. 2016, 11, 025001, https://doi.org/10.1088/17486041/11/2/025001.

66. Sevost'yanov, M.A.; Nasakina, E.O.; Baikin, A.S.; Sergienko, K. V.; Konushkin, S. V; Kaplan, M.A.; Seregin, A. V; Leonov, A. V; Kozlov, V.A.; Shkirin, A. V; Bunkin, N.F.; Kolmakov, A.G.; Simakov, S.V.; Gudkov, S.V. Biocompatibility of new materials based on nano-structured nitinol with titanium and tantalum composite surface layers: experimental analysis in vitro and in vivo. J. Mater. Sci. Mater. Med. 2018, 29, 33, https://doi.org/10.1007/s10856-018-6039-3.

67. Elkaiam, L.; Hakimi, O.; Yosafovich-Doitch, G.; Ovadia, S.; Aghion, E. Correction to: In vivo Evaluation of $\mathrm{Mg}-5 \% \mathrm{Zn}-2 \% \mathrm{Nd}$ Alloy as an Innovative Biodegradable Implant Material. Ann. Biomed. Eng. 2019, 47, 2515-2515, https://doi.org/10.1007/s10439-019-02378-y.

68. Müller, R.; Abke, J.; Schnell, E.; Macionczyk, F.; Gbureck, U.; Mehrl, R.; Ruszczak, Z.; Kujat, R.; Englert, C.; Nerlich, M.; Angele, P. Surface engineering of stainless steel materials by covalent collagen immobilization to improve implant biocompatibility. Biomaterials 2005, 26, 6962-6972, https://doi.org/10.1016/j.biomaterials.2005.05.013. 